УДК 355.233 (477)

Олександр ВасильсЕ

Національний університет оборони

України імені Івана Черняховського, м. Київ

ORCID ID 0000-0002-9492-5594

DOI: $10.33099 / 2617-1775 / 2019-02 / 23-32$

\title{
МЕТОДОЛОГІЧНІ ОСНОВИ ДОСЛІДЖЕННЯ СТРУКТУРИ І ЗМІСТУ ПЕДАГОГІЧНОЇ ДІЯЛЬНОСТІ ВИКЛАДАЧА ВИЩОГО ВІЙСЬКОВОГО НАВЧАЛЬНОГО ЗАКЛАДУ
}

Стаття присвячена дослідженню структури й змісту педагогічної діяльності викладача вищого військового навчального закладу, ї впливу на досягнення якісних змін у системі вищої військової освіти. На основі систематизації методологічних підходів, теоретичних і прикладних положень про сутність, зміст і структуру професійно-педагогічної діяльності розкриваються морфологічний, аксиологічний, праксеологічний й онтологічний аспекти педагогічної діяльності викладача ВВНЗ.

Ключові слова: педагогічна діяльність; викладач; вищий військовий навчальний заклад; управління прочесом педагогічної діяльності; етапи професійного становлення викладача; професійна компетентність.

Вступ. Сучасні вимоги до рівня професійної компетентності військових фахівців з урахуванням бойового досвіду застосування Збройних Сил України обумовлюють принципові зміни в організації й змісті військової освіти. Ефективність реалізації заходів щодо вдосконалювання системи підготовки військових кадрів у значній мірі залежить від професіоналізму викладачів вищих військових навчальних закладів (далі - ВВНЗ).

Постановка проблеми. Визначальним показником ефективності діяльності системи військової освіти, ВВНЗ, військових навчальних підрозділів закладів вищої освіти є якість підготовки військових фахівців [1, с. 25].

Для досягнення якісних змін у системі військової освіти недостатньо лише перегляду навчальних планів і програм, термінів навчання, збільшення переліку навчальних дисциплін, перерозподілу навчального часу та інших організаційнометодичних заходів. Сучасна суспільно-політична ситуація потребує іншої парадигми освіти, тобто корінного змінення структури та змісту освітнього процесу, вдосконалення педагогічної діяльності та професійної компетентності викладачів.

Це зумовило й динаміку змін української системи освіти від когнітивноорієнтованої до особистісно-орієнтованої парадигми та появи й утвердження компетентнісно-орієнтованої парадигми, яка набула статусу новітньої міжнародної освітньої стратегії [2].

Аналіз останніх досліджень i публікацій. Проблемі професійної компетентності особистості присвячені дослідження багатьох вітчизняних та зарубіжних учених, праці яких зосереджені, перш за все, на освітянах - учителях та викладачах вищих навчальних закладів (далі - ВНЗ). Фундаментальні основи оновлення системи професійної підготовки педагогів вищої школи, теоретичні та методичні засади формування професіоналізму, професійної культури, професійної 
майстерності і, власне, професійної компетентності викладачів ВНЗ розкриваються в працях В.П. Андрущенка, В.І. Бондаря, Н.В. Гузій, О.А. Дубасенюк, І.Ф. Ісаєва, Н.В. Кузьміної, Н.Г. Протасової, В.А. Семиченко, В.О. Сластьоніна, В.І. Тесленка та ін.

У наукових дослідженнях значне місце відводиться психологічному та спеціально-педагогічному компонентам як основним складовим такого системного явища, як професійна компетентність педагога (О.О. Бодальов, Н.В. Кузьміна, А.К. Маркова, Л.М. Мітіна, В.О. Сластьонін).

Результати досліджень проблеми компетентності особистості у психологопедагогічній науці, взагалі, та професійній педагогіці, акмеології, психології i педагогіці вищої школи, зокрема, використовуються при вирішенні широкого кола теоретичних й прикладних питань, спрямованих на вивчення цього феномену в контексті професійного становлення, розвитку і самовдосконалення особистості як суб'єкта професійної діяльності (К.О. Абульханова-Славська, О.О. Бодальов, А.О. Деркач, Н.В. Кузьміна, Е.Ф. Зеєр, І.О. Зимня, А.К. Маркова, Л.М. Мітіна, В.О. Сластьонін, В.А. Семиченко, С.Д. Смірнов, Ю.Г. Фокін, В.Д. Шадриков та ін.).

У наукових працях по педагогіці вищої військової школи (Е.Я. Лусс, M.I. Нещадим, В.Н. Новіков, І.О. Хорєв, В.В. Ягупов) охарактеризовані сутність і особливості професійно-педагогічної діяльності військового педагога [3-8].

Мета статті. Вдосконалення педагогічної діяльності викладача ВВНЗ в сучасних умовах характеризується переходом від репродуктивного рівня виконання професійних дій у педагогічному процесі до творчого, інноваційного рівня, ускладненням завдань навчання та виховання тих, хто навчається, підвищенням вимог до професійної компетентності викладача.

У зв’язку із цим актуальним завданням є дослідження процесу формування й розвитку професійної компетентності викладачів ВВНЗ на основі систематизації основних теоретичних i прикладних положень про сутність, зміст і структуру їхньої професійно-педагогічної діяльності. Вихідними передумовами для дослідження даної проблематики є наступні гіпотези:

формування й розвиток професійної компетентності військових педагогів здійснюється в рамках цілісного процесу підготовки, перепідготовки й підвищення кваліфікації викладацького складу ВВНЗ;

процес формування й розвитку професійної компетентності військових педагогів має специфічні особливості щодо цілей, завдань, організації, змісту, методів та інших характеристик даного процесу;

теоретичні й практичні основи процесу формування й розвитку професійної компетентності військових педагогів багато в чому визначаються теорією й практикою вдосконалювання професійно-педагогічної діяльності викладачів цивільних вищих навчальних закладів.

Методи дослідження. Використовувалися такі загальнонаукові методи дослідження: аналіз і синтез, індукція та дедукція, системний підхід до розгляду проблеми та виконання наукового завдання даної статті. 
Виклад основного матеріалу. Провідним методом дослідження щодо оновлення, вдосконалення будь-якої системи, у тому числі й педагогічної, вважається моделювання [9]. Моделювання професійно-педагогічної діяльності військового педагога - це визначення цілісний сукупності іiі основних складових, насамперед, складових структури і змісту педагогічної діяльності викладача ВВНЗ.

Наприклад, у роботі В.И. Вдовюка і Г.А. Шабанова розкриваються три основних аспекти професійно-педагогічної діяльності викладача вищої військової школи: соціально-педагогічний, нормативно-змістовний i функціонально-психологічний [10, с. 50-52].

У науковій праці Г.В. Суходольского запропонований базисний підхід системного опису діяльності як такий, що охоплює морфологію (сутність і структуру), аксиологію (потреби, цінності, оцінки), праксеологію (розвиток і функціонування), онтологію (існування, характеристика, пізнання) [11]. Для аналізу професійно-педагогічної діяльності військового педагога був використаний даний підхід в силу його універсальності [12].

Дослідження морфологічного аспекту педагогічної діяльності викладача ВВНЗ дозволяе виявити іiі сутність і структуру. На основі зіставлення ряду дефініцій педагогічної діяльності можна зробити висновок про те, що одним 3 характерних ï ознак $є$ доцільність, спрямованість на досягнення цілей навчання й виховання.

Цільова спрямованість і зміст педагогічної діяльності військового педагога визначаються освітніми програмами, професійними стандартами, навчальними планами й програмами навчальних дисциплін, у яких ураховуються сучасні тенденції розвитку військового справи й Збройних Сил, досвід застосування військ (сил).

При цьому, будучи уявним поданням результату, поставлені цілі навчання й виховання військових фахівців дозволяють здійснювати постійну корекцію педагогічної діяльності для більш повної відповідності реальному результату. Слід зазначити, що в процесі цілеспрямування багато викладачів зазнають певних труднощів, що обумовлено необхідністю трансформувати загальні цілі підготовки офіцерських кадрів в індивідуальні педагогічні цілі конкретного викладача.

Успішність реалізації цілей педагогічної діяльності залежить від багатьох факторів, у тому числі від індивідуальних професійних домагань і мотивації викладача. Рівень домагань і мотивації визначається самооцінкою викладачем себе як професіонала в минулому (ретроспективна професійна самооцінка), у сьогоденні (актуальна професійна самооцінка) і в майбутньому (потенційна й ідеальна професійна самооцінка).

Вивчення морфологічного аспекту педагогічної діяльності припускає також виявлення іiі структури. У системології під структурою розуміються відносини або сукупність відносин між різними елементами системи. Різноманіття структурних елементів педагогічної діяльності обумовлює іiі 
поліструктурність. Для дослідження були виділені логічна, функціональна, технологічна й інформаційна структури педагогічної діяльності [13].

Аналіз логічної структури педагогічної діяльності дозволяє визначати вихідні параметри для іiі здійснення: мету, завдання й рівні підготовки військових фахівців (професійний стандарт); структуру й зміст навчання (освітні програми, навчальні плани й програми навчальних дисциплін); послідовність і логіку вивчення навчальних дисциплін (структурно-логічні схеми, робочі навчальні програми).

В основу дослідження функиіональної структури педагогічної діяльності був покладений iï функціонально-психологічний аспект, що припускає виділення гностичної (пізнавальної), організаторської, конструктивної, виховно-розвиваючої, комунікативної, інформаційної, мотиваційної й дослідницької функцій [14, с. 53].

Технологічна структура педагогічної діяльності характеризує ії як процес рішення педагогічних завдань i розкриває основні етапи цього процесу, зокрема:

діагностування педагогічних ситуацій, прогнозування перспектив їхнього розвитку; вивчення основних характеристик педагогічних ситуацій i педагогічної діяльності;

проектування (моделювання) дій по виходу зі складних педагогічних ситуацій за допомогою рішення педагогічних завдань;

реалізація ухваленого рішення на практиці (здійснення педагогічних впливів);

аналіз процесу й результатів педагогічної діяльності, підготовка рекомендацій з їі корекції [15, с. 47-48].

Виділення інформаційної структури в якості самостійного системного компонента обумовлено великою інформаційною насиченістю педагогічної діяльності. Інформаційна структура включає інформаційні носії, властиво інформацію у вигляді певних знакових систем, інформаційні канали, банки інформаційних даних.

Аксиологічний аспект педагогічної діяльності передбачає дослідження, насамперед, iї результативно-мотиваційної сторони. 3 метою підвищення об'єктивності даних дослідження виявлення мотивів педагогічної діяльності буде здійснюватися як на основі анкетування викладачів ВВНЗ, так і на основі відомостей, отриманих у керівного складу військових університетів, академій, інститутів, факультетів і кафедр. Результати дослідження аксиологічного аспекту педагогічної діяльності дозволять з'ясувати особливості мотивації викладача ВВНЗ.

Аксиологічні підстави становлення й розвитку професіоналізму педагогічної діяльності викладача поки ще не одержали належного висвітлення, хоча аналіз практики свідчить, що ціннісні орієнтації викладача, його естетичні установки, морально-психологічні відношення до інших людей мають вирішальне значення при визначенні педагогічних завдань і пошуку шляхів їхнього рішення [16]. 
Дослідження педагогічної діяльності в праксеологічному аспекті припускає аналіз двох взаємозалежних процесів: функціонального й розвитку. Найбільш важливим представляється вивчення процесу розвитку, що дозволяє розкрити механізм удосконалювання педагогічної діяльності [17].

Дослідження педагогічної діяльності як функціонального процесу припускає проведення аналізу двох основних компонентів: репродуктивного (відтворення основних елементів і відносин педагогічної діяльності) і творчого (використання інновацій). Інновації в педагогічній діяльності, що породжені творчістю педагога, спочатку одержують індивідуальне (деякими викладачами), а потім соціальне визнання (педагогічними колективами кафедр, факультетів, інституту й інших навчальних закладів).

Поширення інновацій здійснюється шляхом індивідуального й колективного повторення, а також масового впровадження нових педагогічних ідей, методів і прийомів, що надалі приводить до їхнього поступового старіння. Відновлення старих елементів педагогічної діяльності й старіння нових елементів - діалектично взаємозалежні сторони вдосконалення педагогічної діяльності викладача.

Розглянемо онтологічний аспект дослідження педагогічної діяльності викладача ВВН3. Конструктивне перетворення педагогічної діяльності неможливо без дослідження іï онтологіï, тобто процесу існування, якісних характеристик i функцій пізнання. По способу існування варто розрізняти актуальне (педагогічна практика, рішення педагогічних завдань) і потениійне (розвиток педагогічної теорії й педагогічні інновації) існування педагогічної діяльності.

Аналіз педагогічної діяльності як об'єктивної й суб'єктивної реальності дозволяє виявити іiї діалектичний характер. Діалектика проявляється у взаємодії й взаємопереходах об'єктивного й суб'єктивного компонентів діяльності. Педагогічні теорії як науковообгрунтований педагогічний досвід (об'єктивне) освоюються й застосовуються викладачем 3 урахуванням індивідуальнопсихологічних особливостей його особистості (суб'єктивне). Особистий досвід одного педагога (суб'єктивне), що визнаний i успішно застосовуваний на практиці багатьма викладачами, згодом узагальнюється й одержує статус теорії (об'єктивне). Аналогічний прояв діалектичного характеру має актуальне й потенційне існування педагогічної діяльності.

На процес здійснення педагогічної діяльності впливають три рівні управління системою військової освіти:

перший - нормативно-регулюючий вплив органів військового управління, яким підпорядковані ВВНЗ;

другий - управлінська й організаторська діяльність керівництва ВВНЗ по здійсненню освітнього процесу й педагогічної діяльності викладачів;

третій - діяльність факультетів і кафедр по вдосконаленню професіоналізму викладачів.

Викладачі “переробляють” вимоги суб'єктів управління системою військової освіти через призму своїх особистісних переконань, мотивів i 
інтересів. При наявності стійкої позитивної мотивації на досягнення професійної компетентності військовий викладач використовує методи й прийоми самовдосконалення, проявляє творчий підхід до педагогічної праці, коректує стиль своєї педагогічної діяльності [18].

Продуктивним $є$ таке управління процесом педагогічної діяльності, коли суб' єкт-суб' єктні відносини між всіма рівнями управління системою військової освіти мають характер рівноправної взаємодії й співробітництва.

При цьому між ними повинен здійснюватися зворотний зв'язок: на основі моніторингу процесу педагогічної діяльності викладачів ВВНЗ органи управління системою військової освіти реалізують погоджені рішення по вдосконалюванню освітнього процесу й аналізують ефективність вжитих заходів з метою внесення своєчасних коректив.

У процесі педагогічної діяльності військовий викладач опановує науковотеоретичними й спеціальними психолого-педагогічними знаннями, навичками й уміннями, що дозволяють якісно реалізовувати педагогічні цілі по підготовці висококваліфікованих військових фахівців. Основою вдосконалювання педагогічної діяльності викладача виступають самостійна робота щодо досягнення професійної компетентності, навчання на курсах підвищення кваліфікації, освоєння передового педагогічного досвіду.

Більшість досліджень педагогічної діяльності звичайно обмежуються 3'ясуванням необхідних професійних умінь і визначенням рівня їхньої виразності у викладачів. При цьому підході педагогічна діяльність представляється як набір статичних елементів, поза динамікою процесу професіоналізації викладачів. Відомі наукові дані про структуру педагогічної

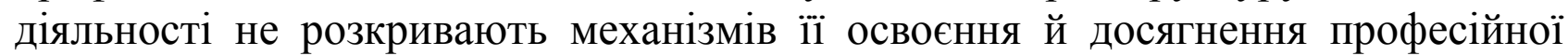
компетентності. Розв'язання цих проблем можливо, на думку автора статті, при спрямованості досліджень на динамічні зміни й розвиток педагогічної діяльності.

Зміст і структура педагогічної діяльності тісно пов'язані 3 етапами професійного становлення викладача. Тому дослідження педагогічної діяльності викладачів ВВНЗ планується проводити в групах педагогів з різним педагогічним стажем:

менш 3-х років;

від 3-х до 10-ти років;

від 10-ти до 15-ти років;

від 15-ти до 20-ти років.

Як відомо, основними засобами реалізації діяльності є дії й операції. Отже, необхідно провести аналіз дій і операцій, що застосовуються при здійсненні педагогічної діяльності.

Дія - це основна одиниця структури діяльності, що представляє собою довільну, навмисну активність, спрямовану на досягнення усвідомлюваної мети. Oперації - це способи виконання дій у відповідних умовах діяльності.

Перспективи подальших досліджень. Дослідження педагогічної діяльності в процесі розвитку дозволить установити зміни ії змісту й структури 
на різних етапах професіоналізації викладачів ВВНЗ. Сучасна педагогічна наука при розгляді концепцій професійного розвитку широко застосовує системний підхід, що припускає вивчення предмета як системи.

Педагогічна діяльність, як і будь-яка інша діяльність, має ряд особливих властивостей. У науковій літературі їх прийнято називати характеристиками. Виявлення характеристик, що найбільш повно відбивають сутність, зміст i специфіку педагогічної діяльності викладача ВВНЗ, передбачається здійснити на основі аналізу їхньої приналежності до морфологічного, аксиологічного, праксеологічного $i$ онтологічного аспектів педагогічної діяльності. Характеристика професіоналізму викладача ВВНЗ повинна містити досить повний перелік найбільш важливих критеріїв щодо якостей особистості викладача, змісту педагогічної діяльності та показників їі результативності [12]. Такий підхід дозволить найбільш повно відбити, як сутнісні, так і специфічні особливості педагогічної діяльності викладача ВВНЗ.

Висновки. Отже, педагогічний професіоналізм викладача ВВН3 - це сукупність професійних, морально-психологічних i особистісних змін, які накопичені у процесі здійснення педагогічної діяльності й забезпечують ефективне рішення складних педагогічних завдань навчання й виховання військових кадрів. Істинно професійної педагогічна діяльність викладача ВВНЗ стає тоді, коли в його діях і мисленні можна виявити наявність і погодженість трьох рівнів і сторін цього процесу: соціального - аксиологічна сторона; функціонального - морфологічна й праксеологічна сторони; особистисноіндивідуального - онтологічна сторона педагогічної діяльності.

\section{ЛІТЕРАТУРА}

1. Телелим В.М., Тимошенко Р.І., Приходько Ю.В. Переосмислення навчання офіцерів. // Оборонний вісник - 2015. - № 1. - С. 24-32.

2. Родигіна І.В. Компетентнісно орієнтований підхід до навчання / I.В. Родигіна. Харків: Вид. група “Основа", 2005. - 96 с.

3. Лусс Е.Я. Актуальні проблеми педагогіки вищої військової школи / Е.Я. Лусс. Харків: ХВУ, 2001. - 423 с.

4. Нещадим M.І. Військова освіта України: історія, теорія, методологія, практика: [монографія] / М.І. Нещадим. - К.: Видавничо-полігріфічний центр “Київський університет”, 2003. $-852 \mathrm{c}$.

5. Новиков В.Н. Развитие теории и практики военно-педагогического образования / В.Н. Новиков. - М.: ВАСН имени Петра Великого, 1999. - 167 с.

6. Хорєв І.О. Дидактика вищої військової школи: [навчальний посібник] / I.О. Хорєв. К.: НАОУ, 2004. - 160 с.

7. Ягупов В.В. Військова дидактика: [навчальний посібник] / В.В. Ягупов - К.: Видавничо-полігріфічний центр “Київський університет”, 2000. - 400 с.

8. Ягупов В.В. Теорія і методика військового навчання: [монографія] / В.В. Ягупов. К.: Тандем, 2000. - 380 с.

9. Введенський В.Н. Моделювання професійної компетентності педагога / В.Н. Введенський // Педагогіка. - 2003.- № 10. - С. 51-55.

10. Вдовюк В.И. Педагогика высшей военной школы. Современные проблемы в структурно-логических схемах и таблицах: [учеб. пособие] / В.Н. Вдовюк , Г.А. Шабанов. M.: ВУ, 1996. -118 c. 
11. Суходольский Г.В. Основы психологической теории деятельности. - Л.: ЛГУ, 1991. - 168 с.

12. Васильєв О.М. Системний підхід до визначення критеріїв професійної компетентності викладача ВВНЗ / О.М. Васильєв // Військова освіта: Зб. наук. праць. 2007. - № 2 (20). - C. 48-57.

13. Васильєв О.М. Структура й особливості професійно-педагогічної діяльності викладача вищого військового навчального закладу / О.М. Васильєв // Сучасні тенденції та перспективи розвитку освіти і науки у вищих навчальних закладах України: Матеріали Всеукраїнської науково-теоретичної конференції. - Хмельницький, 2006. - С. 181-184.

14. Гура О.І. Психолого-педагогічна компетентність викладача вищого навчального закладу: теоретико-методологічний аспект: [монографія] / O.I. Гура. - Запоріжжя: ГУ “ЗІДМУ”, 2006. - 332 с.

15. Подласый И.П. Диагностика и экспертиза педагогических проектов / И.П. Подласый. - К., 1998. - 318 с.

16. Бібік Н.М. Компетентнісний підхід: рефлексивний аналіз застосування // Компетентнісний підхід у сучасній освіті: світовий досвід та українські перспективи: Бібліотека з освітньої політики. - К.: “К.І.С.”, 2004. - С. 47-52.

17. Лобанова Н.М. Професійна компетентність і етапи ii становлення в діяльності педагога / Н.М. Лобанова // Проблеми освіти: Наук.-метод. збірник. - К., 1999. - С. 232-236.

18. Васильєв О.М. Сучасні вимоги до професійної компетентності викладача вищого військового навчального закладу / О.М. Васильєв // Кредитно-модульна технологія навчання та методичне забезпечення контролю якості успішності: Матеріали Всеукраїнської науковопрактичної конференції. - Полтава, 2006. - С. 142-144.

\section{REFERENCES}

1. Telelym V.M., Tymoshenko R.I., Prykhodko Y.V. Pereosmyslennia navchannia ofitseriv. // Oboronnyi visnyk - 2015. - № 1. - S. 24-32. (in Ukrainian)

2. Rodyhina I.V. Kompetentnisno oriientovanyi pidkhid do navchannia / I.V. Rodyhina. Kharkiv: Vyd. hrupa "Osnova", 2005. - 96 s. (in Ukrainian)

3. Luss E.I. Aktualni problemy pedahohiky vyshchoi viiskovoi shkoly / E.I. Luss. - Kharkiv: KhVU, 2001. - 423 s. (in Ukrainian)

4. Neshchadym M.I. Viiskova osvita Ukrainy: istoriia, teoriia, metodolohiia, praktyka: [monohrafiia] / M.I. Neshchadym. - K.: Vydavnycho-polihrifichnyi tsentr "Kyivskyi universytet", 2003. - 852 s. (in Ukrainian)

5. Novykov V.N. Razvytye teoryy y praktyky voenno-pedahohycheskogo obrazovanyia / V.N. Novykov. - M.: VASN imeny Petra Velykogo, 1999. - 167 s. (in Russian)

6. Khoriev I.O. Dydaktyka vyshchoi viiskovoi shkolu: [navchalnyi posibnyk] / I.O. Khoriev. - K.: NAOU, 2004. - 160 s. (in Ukrainian)

7. Yahupov V.V. Viiskova dydaktyka: [navchalnyi posibnyk] / V.V. Yahupov - K.: Vydavnycho-polihrifichnyi tsentr "Kyivskyi universytet", 2000. - 400 s. (in Ukrainian)

8. Yahupov V.V. Teoriia i metodyka viiskovogo navchannia: [monohrafiia] / V.V. Yahupov. - K.: Tandem, 2000. - $380 \mathrm{~s}$.

9. Vvedenskyi V.N. Modeliuvannia profesiinoi kompetentnosti pedahoha / V.N. Vvedenskyi // Pedahohika. - 2003.- № 10. - S. 51-55. (in Ukrainian)

10. Vdoviuk V.Y. Pedahohyka vusshei voennoi shkolu. Sovremennыe problemb v strukturno-lohycheskykh skhemakh y tablytsakh: [ucheb. posobye] /V.N. Vdoviuk, H.A. Shabanov. - M.: VU, 1996. - 118 s. (in Russian)

11. Sukhodolskyi H.V. Osnovu psykholohycheskoi teoryy deiatelnosty. - L.: LHU, 1991. 168 s. (in Russian)

12. Vasyliev O.M. Systemnyi pidkhid do vyznachennia kryteriiv profesiinoi kompetentnosti vykladacha VVNZ / O.M. Vasyliev // Viiskova osvita: Zb. nauk. prats. - 2007. - № 2 (20). - S. $48-$ 57. (in Ukrainian) 
13. Vasyliev O.M. Struktura y osoblyvosti profesiino-pedahohichnoi diialnosti vykladacha vyshchoho viiskovoho navchalnoho zakladu / O.M. Vasyliev // Suchasni tendentsii ta perspektyvy rozvytku osvity i nauky u vyshchykh navchalnykh zakladakh Ukrainy: Materialy Vseukrainskoi naukovo-teoretychnoi konferentsii. - Khmelnytskyi, 2006. - S. 181-184. (in Ukrainian)

14. Hura O.I. Psykholoho-pedahohichna kompetentnist vykladacha vyshchoho navchalnoho zakladu: teoretyko-metodolohichnyi aspekt: [monohrafiia] /O.I. Hura. - Zaporizhzhia: HU “ZIDMU”, 2006. - 332 s. (in Ukrainian)

15. Podlasui Y.P. Dyahnostyka i ekspertyza pedahohycheskykh proektov. - K., 1998. - 318 s. (in Russian)

16. Bibik N.M. Kompetentnisnyi pidkhid: refleksyvnyi analiz zastosuvannia // Kompetentnisnyi pidkhid u suchasnii osviti: svitovyi dosvid ta ukrainski perspektyvy: Biblioteka $\mathrm{z}$ osvitnoi polityky. - K.: "K.I.S.”, 2004. - S. 47-52. (in Ukrainian)

17. Lobanova N.M. Profesiina kompetentnist i etapy yii stanovlennia v diialnosti pedahoha / N.M. Lobanova // Problemy osvity: Nauk.-metod. zbirnyk. - K., 1999. - S. 232-236. (in Ukrainian)

18. Vasyliev O.M. Suchasni vymohy do profesiinoi kompetentnosti vykladacha vyshchogo viiskovogo navchalnogo zakladu / O.M. Vasyliev // Kredytno-modulna tekhnolohiia navchannia ta metodychne zabezpechennia kontroliu yakosti uspishnosti: Materialy Vseukrainskoi naukovopraktychnoi konferentsii. - Poltava, 2006. - S. 142-144. (in Ukrainian)

\title{
PЕЗЮМЕ
}

\author{
Александр Васильев, \\ Национальный университет обороны \\ Украины имени Ивана Черняховского, г. Киев
}

\section{Методолические основи исследования структури и содержания педагогической деятельности преподавателя высшего военного учебного заведения}

\begin{abstract}
Статья посвящена исследованию структуры $u$ содержания педагогической деятельности преподавателя высшего военного учебного заведения, ёё влияния на достижение качественных изменений в системе высшего военного образования. На основе систематизации методологических подходов, теоретических и прикладных положений о сущности, содержании и структуре профессионально-педагогической деятельности раскрываются морфологический, аксиологический, праксеологический и онтологический аспекты педагогической деятельности преподавателя ВВУЗа.

Ключевые слова: педагогическая деятельность; преподаватель; высшее военное учебное заведение; управление прочессом педагогической деятельности; этапь профессионального становления преподавателя; профессиональная компетентность.
\end{abstract}

\section{SUMMARY}

Oleksandr Vasyliev,

National Defense University of Ukraine named after Ivan Cherniakhovskyi, c. Kyiv

\section{Methodological basis of research of the structure and of the content of pedagogical activity of a teacher of higher military educational institutions}

Introduction. The current socio-political situation requires a different paradigm of education, a radical change in the structure and content of the educational process, improvement of pedagogical activity and professional competence of teachers. 
Purpose. The urgent task is to study the process of formation and development of professional competence of teachers of higher education institutions on the basis of systematization of the basic theoretical and applied provisions on the nature, content and structure of their professional and pedagogical activity.

Methods. The following general scientific methods of research were used: analysis and synthesis, induction and deduction, systematic approach to consideration of a problem and performance of scientific task of this article.

Results. Most pedagogical studies are usually limited to finding the necessary professional skills and determining the level of their expressiveness in teachers. In this approach, pedagogical activity is presented as a set of static elements, outside the dynamics of the process of professionalization of teachers. The content and structure of pedagogical activity are closely related to the stages of teacher's professional development. Therefore, it is suggested to study pedagogical activity of teachers of higher education institutions in groups of teachers with different pedagogical experience.

Originality. Well-known scientific data on the structure of pedagogical activity do not reveal the mechanisms of its development and achievement of professional competence. According to the author of the article, these problems can be solved only if the research focuses on dynamic changes and development of pedagogical activity.

Conclusion. Characteristics of the professionalism of the teacher of the university must contain a fairly complete list of the most important criteria regarding the qualities of the teacher's personality, the content of pedagogical activity and indicators of its effectiveness. Further studies of pedagogical activity in the process of development will allow establishing changes of its content and structure at different stages of professionalization of teachers of high schools.

Key words: pedagogical activity; teacher; higher military educational institution; management of the process of pedagogical activity; stages of professional formation of the teacher; professional competence. 